\title{
Temporality 1: Heidegger's analysis of time and its relation to psychoanalytic theory
}

\author{
Paul Cammell ${ }^{1}$ \\ Department of Psychiatry
}

\begin{abstract}
In this article I attempt to demonstrate the relevance of the philosophy of time to psychiatric, psychological and psychoanalytic theories of development and therapeutic action. I choose to explore and analyse the writings of Martin Heidegger, arguably the twentieth century's pre-eminent philosopher of time. I then develop links between his philosophy and Freudian theories of time, and in particular Freud's notion of Nachträglichkeit, as advanced in the writings of André Green and Jacques Derrida. I conclude by advancing a range of temporal concepts that may be employed in the analysis of developmental theories and clinical approaches. In an accompanying article I undertake such an analysis, relating in particular to borderline conditions.
\end{abstract}

\section{Introduction}

In a broad sense, time, or temporality, permeates all aspects of our work as clinicians working in the fields of psychotherapy, psychiatry and psychology. When we think about our patients this occurs both in the retrospective sense when we consider case histories, developmental formulations and aetiology as well as in the prospective sense when we consider therapeutic goals and processes, the course of treatment and the nature of termination of treatment. With temporality being such an integral or essential element of our work, is there a way in which we can think about time philosophically, and bring this into a discussion of temporality in the clinic?

In this article, I intend to undertake such an analysis through an exploration of the philosophy of Martin Heidegger, arguably the twentieth century's pre-eminent philosopher of time, going on to explore the affinities his philosophy has with Freudian psychoanalytic theories of time, traces of which are found in Freud's original corpus of work, but were then analysed or advanced more fully by psychoanalyst André Green and philosopher Jacques Derrida. Then in an accompanying article, I intend to explore how this theoretical analysis of temporality is relevant to our consideration of development and clinical work, focussing in particular on borderline conditions.

\footnotetext{
${ }^{1}$ Correspondence concerning this article should be addressed to Dr. Paul Cammell, Department of Psychiatry, Flinders Medical Centre, Bedford Park, South Australia, 5152, Australia. E-mail: paul.cammell@health.sa.gov.au
} 


\section{Heideggers' Philosophy}

Martin Heidegger's philosophy has been increasingly noted to have many affinities and relations with psychodynamic theory, psychotherapy and psychoanalysis. Later in his career, Heidegger (1959-1969) himself held the Zollikon Seminar regularly for over ten years with a group of psychiatrists and psychoanalysts in Switzerland. In these seminars Heidegger approached the task of elaborating the implications of his thought (the ontological, phenomenological and hermeneutic standpoints) for clinicians. Alongside this, his ideas were separately developed and adapted by Ludwig Binswanger and Medard Boss into schools of existential psychoanalysis (Binswanger, 1963; Boss, 1963, 1979). Heidegger (1959-1969) himself critically responded to this and elaborated what are some of the philosophical difficulties in building a systematic clinical approach (in a clinicalscientific domain) from his own philosophical approach, which is concerned with different questions to do with broader philosophical domains such as ontology, phenomenology and hermeneutics.

The question then becomes how philosophical ideas can be brought into dialogue with, or influence, thinking in a different though related clinical domain. There is already a precedent of this having occurred more broadly with Heideggerian philosophy and the clinical domain of psychoanalysis: Herman Lang (1997), for example, trained under Hans-Georg Gadamer (one of Heidegger's principle followers) and wrote about Heideggerian and Lacanian conceptualizations of language and the unconscious; and Hans Loewald (1978, 1980), a student of Heidegger in the 1930s, and subsequently a preeminent North American psychoanalyst, wrote in an apparently orthodox Freudian style which nevertheless shows obvious influences from his hermeneutic and phenomenological training. In the writings of both of these thinkers, one can see the influences that Heidegger's form of hermeneutic stance can have in its application to a clinical field. There are also representatives of the intersubjective, interpersonal and relational schools, such as Orange, Stolorow and Atwood (for example see Stolorow 2002 and 2007; Stolorow, Atwood and Orange, 2002; and Stolorow, Orange and Atwood, 2001) as well as other analytic thinkers with philosophical training or interests, such as William Richardson, Louis Sass, Alan Bass and André Green, who have drawn reference to Heidegger's work and other thinkers of the hermeneutic tradition. And, finally, there are those philosophers who have either advanced a hermeneutic orientation and then engaged with the fields of psychoanalysis, psychotherapy and psychiatry (for example Hans Georg Gadamer and Paul Ricoeur), or have developed their own orientation that has then been related to these fields at the same time as being related to but distinguished from Heidegger's work (for example Jacques Derrida and Emmanuel Levinas).

With the benefit of all of these vantage points, the discussion below will attempt to elucidate a hermeneutic frame or perspective from which to approach the theoretical and clinical domain of borderline experience. This will first involve an elaboration of aspects of Heidegger's (1928) early writing, and in particular, his ideas around time and temporality.

Heidegger's own methodology was developed from two disciplines: the first being hermeneutics (loosely, the study of methods of interpretation, originally of scripture and other texts, but broadened to any form of human actions, utterances or practices amenable to understanding); and the second being phenomenology (loosely the study of one's immediate perceptions and experiences). His early principle work Being and Time (1928) was the beginning part of an enormous project aimed at a general theory of Being 
(ontology) which began with an exploration of the specific nature of the existence of human beings. What is significant for us, here, is that Heidegger, along with other eminent contemporaries such as Merleau-Ponty and Wittgenstein, elaborated a type of framework that undermines any decontextualized, individualistic notion of the self seen as a discrete autonomous agent, who divorced from the world processes the data of experience (perception, interaction with others) in a representational, algorithmic way. Heidegger's notion of Dasein (literally "being-there") and being-in-the-world indicates our irreducible and unsurpassable "embeddedness" in a concrete and contingent "life world" - we are always already in the world, practically immersed in the necessities and activities of life as an existential project into which we are thrown as finite beings. It is an inescapable context in which our being is already shared with others, housed in language, immersed in time within the horizon of death. In this context, our being, our self, is always an issue for us. But it is only from within this context that as selves we may begin to attempt to understand or explain who or what we are. This context is a background we can never fully master as we are always already a part of it. Heidegger holds that we exist within this context or horizon of being with an implicit understanding or what he might call a pre-understanding of how to go about things, with at the same time the possibility of explaining or explicitly understanding the nature of our being something which is furthest away from us.

Heidegger's exploration, with Nietzsche before him, of this notion of an existential limit, and the idea of self-estrangement and an opaque background to our being, I believe, is significant for our understanding of selfhood as clinicians. It has a bearing upon how we think about dimensions of the self that are implied in notions like the Unconscious. It also has a bearing upon how we can think about all of these concrete and very real elements of existence involved in the rich spectrum of our affective, interpersonal and embodied experiences. Now Heidegger affirms that all of these elements of existence are intrinsically temporal and to understand this we need to explore his project of Being and Time (1928) in some more depth.

\section{Heidegger's Hermeneutic Ontology}

Heidegger opens his foundational work Being and Time (1928) by referring to the entire history of philosophy as a "forgetting" of the "question of Being". In talking about this "forgetting", Heidegger (1928) is referring to philosophical thought from Plato and Aristotle onwards but is also including the modern scientific disciplines that emerged out of metaphysics in the seventeenth century and subsequent humanistic disciplines such as psychology and anthropology. Heidegger's project begins with an attempt to recover this "question of Being"- find an opening or a clearing in which to think about Being again. This will require a methodology of interpretation, a hermeneutic method, which will involve partly reading what has become omitted or hidden in philosophical discourse (but somehow remained implicit to it) in order to reveal it and allow it to be openly apprehended. The other element of his method of approaching the "question of Being" for Heidegger will be phenomenological insofar as it concentrates on what is experientially immediate and apparently self-evident to all of us. It is governed by phenomenology's principle of principles - the principle of presence and of the presence in self-presence, such as it is manifested in the Being that we ourselves are (our experience of what seems self-evident including our self awareness or self-consciousness). It is this proximity of Being to itself, and our questioning of Being to our own Being, that intervenes in Heidegger's choice or deduction of the exemplary form of Being for his 
analysis - what he calls Dasein (literally "being there"). Heidegger's point is that we who are close to ourselves, we interrogate ourselves about the meaning of Being. This interrogation, as a process of interpretation, occurs within this "hermeneutic circle of Being".

To explain what is important about this notion of a "hermeneutic circle" I could refer to moments when Heidegger (1929) links this starting point for interpreting Being with the Kantian origins of an attempt to instigate a "Copernican Revolution" in metaphysics. This revolution relates to a reversal of the common-sense view of the subject-object distinction, specifically regarding the knowing subject and the object known. Just because it locates the ground of any knowledge of any object within the knowing subject, Kant's revolution represents, as Heidegger recognized, the first serious attack on the traditional Platonic-Aristotelian approach to insight into the nature of things by focussing on that which needs to be known (the objects themselves or "things in themselves"). For Kant, in contrast to the Aristotelian tradition, thought does not know the thing itself without any intermediary: thought merely interprets what sense-intuition "reports". The concept is not "necessarily in conformity with its object"; in fact, the Copernican Revolution proclaims the reverse: it is the object that, to be known, must conform to the knowing requirements of the knower - for Kant, the transcendental categories. These transcendental conditions govern the synthesizing operation of our immediate apprehensions and our pure concepts - they, in a way, permit existent things to be recognized. The "beyond" of this knowing, the noumenal, is unknowable. Kant thus brought us to the point where the ground of the presence or absence of an object in knowledge is to be seen within the nature of the knower. He has thus created the possibility of a new form of enquiry - namely, "the metaphysics of the subject". Heidegger's approach would be, then, that the invocation of transcendental laws regarding the how-and-what we can know concerns precisely the condition and nature of being - and moreover, the meaning of "Being" and the copula "is" in themselves. This, of course, is precisely the original motivation and orientation for Heidegger's "fundamental ontology" (the hermeneutic and phenomenological enquiry into the Question of Being). It is not the place to explore the relationship between Kant's transcendental philosophy and Heidegger's fundamental ontology any further so much as to point out that for Heidegger the hermeneutic circle simultaneously refers to selfunderstanding (the phenomenology of self-interpretation) and philosophical understanding (interpreting Being evolving through the history of philosophy). Both relate to thinking about Being through interpretation and approaching this through what is present phenomenologically and not objectively. For Heidegger, phenomenological interpretation is descriptive and opens a space to make thinking possible: it is about potentiality.

Heidegger's own revolution, then, is to re-situate and broaden out our notions of understanding and interpretation beyond them being, simply, methods of reading or procedures of critical reflection. Understanding and interpretation become modes of being: the universal, pre-reflective mode in which we conduct ourselves in the world is itself of a hermeneutic nature. The world is familiar to us through basic, intuitive ways of going about things, where tacit and intuitive approaches, pragmatic forms of know-how, predominate. Most originally, Heidegger argues, we do not begin by understanding the world simply through the acquisition of objective facts, algorithms or representational knowledge from which we can establish or derive universal propositions, laws, or judgments that, to a greater or lesser extent, correspond to the world. The world is already implicitly intelligible to us, familiar to us, something with which we are at home. Explicit 
understanding and interpretation follow this, or co-exist with this. The hermeneutic circle of interpretation, then, refers to the interplay between our self-understanding and our understanding the world. Hermeneutics now deals with the meaning, or limits and lack of meaning in our own lives. This begins with individuals and their own situation, or situatedness.

\section{Heidegger on Temporality}

Arguably the most significant element of his existential analysis relates to the embeddedness of any form of behaviour or action within the situatedness of worldhood involving time and temporality. Importantly, Dasein is formally characterized by Heidegger as having that fundamental self-relation - that "comporting itself to its own Being"-which, above being directed towards and absorbed in any specific worldly activity or goal in the way I have discussed, is ruled by an inherent and intrinsic "directedness" of its own. This manifests itself in any the specific activities we engage in. Put loosely this unifying "directedness" in Dasein is referred to by Heidegger as the "Care Structure": the fact that Dasein intrinsically has "concern" in its existence, no matter what this concern may be for, in its dealings and comportments. At the heart of this is the notion of "Temporality" Heidegger later introduces in Being and Time, as well as that of "Ontological Difference" which Heidegger introduces in The Basic Problems of Phenomenology (1982) around that concept of Temporality.

Through these notions, Heidegger wants to assert that Dasein is not "in time" like other things in its world are. For we are not simply in a "present" which is as a function of its "past", on the way to a "future" which will come to be as a function of that "past and present". Rather, our existence is uniquely led by its "future" - a "future" which is, in effect, guiding, pulling or directing the present in a particular direction out of its past. Specifically, when we are absorbedly coping with a particular task this "future-driven" quality, or "future-directedness", manifests itself in an ability of Entwurf (Projection) which allows a form of Umsicht (practical circumspection) to lead it through specific tasks and more broadly how it goes about anything. This overall directedness is seen by Heidegger to be the unifying aspect of all of our concerns in the world. In this way, Dasein's Being has a unifying "Care Structure" which makes it a "perpetual coming to be" at any possible level. Such capacities as Entwurf and Umsicht are ineliminable and intuitive and not able to be nomologically understood. They cannot be built up from component abilities in some incremental way. They are not programmatic - understood in terms of explicit rules, algorithms, prototypes, formulae. The capacities are general, global, presiding, primordial. They are a base intuition. To understand that this is not just a simple assertion on Heidegger's behalf we must also carry through the formal structure that this concept exists within and in terms of. Heidegger has disclosed it through his hermeneutic phenomenological analysis of Dasein's way of Being within a greater ontological framework driven by a fundamental "Question of Being". This means that Heidegger is in no way making assertions about a type of traditional subjectivity conceived of as a "conscious subject" or "transcendental ego" or "human being or soul". Entwurf and Umsicht, here, only have an import insofar as they are ontological, within Heidegger's own analytic of the ontology of Dasein. This analytic, ultimately, was alluded to as extending to the notion of "Care" which offers a unifying structure to the being that is Dasein, understood within that horizon of Temporality that separates Dasein off, purportedly, from other beings by virtue of an "Ontological Difference" that resides in Being as a whole. 
It only really needs to be noted here, that Heidegger attributes to Dasein's understanding of the roles and identities to which it comports itself, a deep notion of evolution and historicity. Not only are they embedded within the ongoing complexity of Dasein's own existence, but also the evolving history of the culture of Dasein. That is, their fluidity their being adapted, changed, improved - is not only continuing throughout Dasein's own ongoing existence, but has been evolving hitherto over the entire history of the culture of which Dasein is a part.

This ability is at the heart of what Heidegger calls Dasein's "absorbed coping" with the world. Heidegger, invariably, gives it the formal name Verstandnis, or "Understanding", in the sense of the German verb verstehen - "to be competently able to", "to understand how to" (and not in the sense of an explicit "awareness" or "comprehension"). In this way, Heidegger is referring to this ability as an ability of insight - rather than an expert knowledge or a trained expertise. Furthermore, it must not be confused with any specific aptitude, competence or skill - a kind of "know-how" ability, such as being talented at shearing or motorcycle repair. Though Verstandnis certainly intervenes in any such activity, it is not, in any way, the specific skill, competence or capability itself. This is why, in some ways, Heidegger's constant discussions of artisan activities, such as "hammering", may have been a poorly chosen metaphor to link to Verstandnis. For it is only something that allows any possible activity to be performed in a flexible, adaptive and, most importantly, intelligent way.

Across sections 31-32, Heidegger (1928) links this general, abstract ability of Verstandnis with the abilities of Sicht ("sight") and Entwurf ("projection"). At my level of discussion, sight is identifiable with Umsicht ("practical circumspection"), the ability which presides over any activity and allows creative adjustments to be made - a flexible and open-ended approach to the activity that allows Dasein to adapt to any changes and novel circumstances that may arise - so that the activity may always be brought to completion to fruition and the fulfilment of its goal. In terms of Umsicht being characteristic of Verstandnis, it involves no will towards a concrete conceptualisation of the end-product or end-point of the activity - vis-à-vis a formal "blueprint", image or discursive plan of the completed activity; but, rather, it involves an intuitive "working understanding" of the way the activity is "progressing" towards a completeness - and the way this progression can be further aided, or left unhampered and uninhibited, as opportunities knock or obstacles present themselves.

And it is the process that operates when this intuitive Umsicht works its way through activities that Heidegger entitles Entwurf. This Entwurf, ultimately, is what Dasein is conscious of as its overall goal - it is what allows Dasein to see in its current situation and circumstances a manifestation of what is progressing toward that goal. In this way, the goal is only ever explicitly known as a "rough sketch" or "intuitive notion" of what is otherwise just appropriately "seen" as something which must be projected towards something that must be achieved through acting upon what is currently given. When Dasein judges that nothing else needs to be done, then the activity has been completed the goal, previously nothing more than a "towards which", has been attained. Any consciousness or declaration of an explicit goal is only derivative to the underlying "projection" of the "towards which" upon the current circumstances, situation and "predicament" manifesting themselves to Dasein in the environment of the activity. They, in a sense, are only ever ontically derived from the preontological "absorbed coping" that is already active. 
This ontological approach to Dasein's mode of being - Existenz - then, offers us a new way of looking at traditional concepts such as "subject" and "object", "consciousness", "ego", "soul" as well as, ultimately, "being". Importantly, Dasein is formally characterized by Heidegger as having that fundamental self-relation - that "comporting itself to its own Being" - which, above being directed towards and absorbed in any specific worldly activity or goal in the way I have discussed, is ruled by an inherent and intrinsic "directedness" of its own. This manifests itself in any more specific directedness Dasein comports itself towards, whether in the world, to other Daseins in the world, or to itself. Although I cannot really elaborate upon this any more, this unifying "directedness" in Dasein is known simply by Heidegger as the "Care Structure": the fact that Dasein intrinsically has "concern" in its existence, no matter what this concern may be for, in its dealings and comportments.

In the second division of Being and Time (1928) Heidegger does establish the broadest context for the Care structure around Dasein reaching its potentiality for being in terms of authenticity and inauthenticity not only in relation to finite origins of thrownness (one's immediate concerns within a contingent, factical, limited background and context) but also in relation to the unsurpassable horizon of death. Heidegger characterizes death as non-relational, and being-towards-death as, thus, seeming to represent an individual, nonrelational existential horizon. Dasein can authentically exist within this horizon or can inauthentically flee from this horizon by an immersion in public anonymity, what he refers to as das Man or "the They". At the same time, Heidegger does also characterize an authentic form of Care of others, or being-with-others when he describes solicitude: Dasein's capacity to leap ahead (vorspringen) of the Other and assist in a return to authentic being in the world, a return to a realisation of potentiality for being. In outlining the concepts of being-towards-death and solicitude Heidegger opens his analysis of temporality into the existential fields of mortality and communal life.

\section{Tentative Affinities between the Thought of Heidegger and Freud on Time}

Heidegger and Freud share a philosophical heritage in which Kant's "metaphysics of the subject" and the subsequent developments of neo-Kantian and Hegelian thought were met by Nietzsche's nihilistic ideas about the various challenges posed to self-interpretation by unconscious motivations and forms of illusion and self-deception. Both Heidegger and Freud developed approaches to interpretation that paid close attention to reading or interpreting symptomatically what is omitted, hidden, implicit, forgotten or repressed. After Nietzsche, this sensitivity to what is absent, what needs to be revealed, disclosed or brought to light, is also an "historical" sensitivity: for Heidegger, there is an historical narrative of the forgetting of the question of Being and this narrative within the history of philosophy correlates with his hermeneutic exploration of Dasein's own tendencies to immerse or become purposefully absorbed in its environment (Umwelt) working towards various goals and projects (Entwurfen), often not mindful of the existential context into which we have been thrown (our "thrownness" or Geworfenheit) and its horizons (death, our own facticity or what Heidegger would term our historicity). Heidegger would hold that this mode of being in the world conceals or omits a sense of the Being that is immanent and implicit to our going about things but not understood in any explicit way. Furthermore Heidegger would refer to the initial tendency for ourselves (qua Dasein) to understand ourselves and the world as falling into the terms of objective presence (what he calls "ontical" understanding), seeing ourselves as the objective entities that we are in 
the objective world in which we exist. This form of "ontical" understanding entails all of the possible technical and scientific elaborations of understanding self and the world as objective entities and is aligned with the philosophical tradition of Platonic-Aristotelian metaphysics which understands the world in terms of objective presence. Part of Heidegger's project in Being and Time was to elucidate that this forgetting of Being philosophically also entails a distortion in the understanding of time. Put simply time may be officially and scientifically understood as an unfolding of successive objectively present moments in a linear sequence of past, present and future, something that is different, Heidegger will hold, to his phenomenological description of time he will attempt to arrive at in Being and Time. This is representative of the forgetting of the temporal nature of Being. A primary role of interpretation in Heidegger's ontology will be to open up a space in which this Being can be thought, revealing the hidden and undisclosed nature of the temporality of Being. As I have shown, fundamental to this understanding is a conception of the phenomenological or existential structure of temporality, Care (Sorge) which is based in Dasein's thrownness (historicity, factical context), projection (being towards) and how this is involved in its present concern for its world within a broader horizon of solicitude and being-towards-death.

We can think of an analogous type of understanding of what is hidden and what becomes disclosed or revealed when we think of Freud's approach to the interpretation of neurotic symptoms. Neurotic symptoms have an historical nature understood in terms of a theory of infantile sexuality and modes of fixation, repression and regression occurring within the delayed action of unconscious memory. This historical nature is akin to thrownness insofar as it acts on the present and projects itself (and I mean this both in a temporal sense and a Freudian sense) into current activity including the transferential enactments and the remembering, repeating and working through in the analytic session. This hidden form of temporality (unconscious memory, conflict, transference) is counterpoised with the more regulated, official, objective time of the analytic session in the analytic work and an objective sense of what is the past and what is the present. The analytic work, interpretive work, makes historical links and the nature of this interpretive work, working in time, and working with the historical unconscious, is what is of interest here.

\section{Freud and the Temporality of the Unconscious}

This idea of an historical Unconscious is problematic because, for Freud, the unconscious is also often referred to as timeless. We may be familiar with many moments in which Freud refers to the unconscious as "timeless". For example, in his (1915) article "The Unconscious" which appears in his papers on metapsychology, he states:

The processes of the system Ucs. are timeless; i.e. they are not ordered temporally, are not altered by the passage of time; they have no reference to time at all. Reference to time is bound up, once again, with the work of the system $C s$ (p. 186). 
Elsewhere in the paper he does refers to the relational and temporal aspects of the unconscious:

It is a very remarkable thing that the UCs. of one human being can react upon that of another, without passing through the Cs....descriptively speaking the fact is incontestable (p. 193).

And:

the greater part of what we call conscious knowledge must in any case be for very considerable periods of time in a state of latency, that is to say, of being psychically unconscious. When all our latent memories are taken into consideration it becomes totally incomprehensible how the existence of the unconscious can be denied (p. 171).

Here, we are looking at a particular site in Freud's topographical writings where an issue appears that re-emerges in many situations in Freud's work: how atemporal unconscious elements (drives, motivations, conflicts) are influenced by memory; how the Unconscious acts as a system of memory; and how the Unconscious operates relationally as opposed to intrapsychically. One further implication of this relates to how, after Freud renounces his own Seduction Theory, within his conceptualizations of the intrapsychic and unconscious basis of neurotic conflict, any conflict or impact introduced by actual or real past traumatic events operates psychopathologically.

At this level, we need to elucidate the ways in which memory acts upon the present, and how, simultaneously, the present (interpretation, working through) acts upon the past via memory. Memory, here, can become a bidirectional constructive or representative process.

If we place these issues in the context of an attempt to understand the manner in which the Freudian analyst understands the historicity of the analysand and the unconscious work they undertake, we can begin to see how tensions arise when we attempt to understand the temporal or historical nature of the interpretations made: do the interpretations make causative links which relate different forms of objective presence (worldly or intrapsychic events), or do they uncomfortably cross a boundary between the objective presence of worldly objective events and an atemporal intrapsychic realm which is either understood in itself as an objectively present "psychic apparatus" (of drives, instincts) or simply a realm of interpretation (of symbolic primary processes).

The hermeneutic exercise of interpreting the exploration and use of temporal concepts in Freud's works, ultimately, is a difficult and complex one: there is no single work which elaborates upon a theoretical formulation of time, and Freud adopts varying and sometimes contradictory elaborations of notions of history, memory and temporality as 
his project developed over thirty to forty years, and arguably as an open, transforming and sometimes unresolved set of theoretical, clinical ideas within psychoanalysis and beyond in realms such as anthropology, theology and aesthetics. Fortunately, a psychoanalytic theorist, with some philosophical literacy, André Green, conducted this form of hermeneutic project to enable us to make further links between Freud's thinking of time, and Heidegger's hermeneutic ontology. I will now explore this as a means of establishing some of these links that will become useful when I come to contemplate developmental and clinical time in the accompanying article.

\section{Green, Nachträglichkeit and Fragmented Time}

In the work Time in Psychoanalysis (2002) and related papers, Green attempts to extract Freud's thinking about time, memory and working through across the course of Freud's works (pre-psychoanalytic, Structural, Topographic) to extract and map out a psychoanalytic theory of time steeped in Freudian origins. A central concept of Freud's that he focuses upon is Nachträglichkeit which is often translated into English as deferred action and into French as après-coup. Green emphasizes that these translations do not emphasize the bidirectional nature of time that is captured in this concept: memory or past experience can remain suspended in conflict, fixation, repression or disavowal, so that any action on psychic life can be re-appear at a later time with a form of deferred action; but, conversely, a current experience can trigger a movement backwards in time, a regression which returns retroactively to the past state, reintroducing the necessity of its action and the possibility of working through by another means. And so, the bidirectional nature always refers to both a delayed effect and the related reconstruction, or working through of it...to this, Green (2002, p. 41) adopts a pun around the word re-presentation, capturing the idea of a deferred return, and a new reconstruction. I will emphasize this notion of re-presentation to capture Green's rediscovery of the bidirectional action of Nachträglichkeit as an active and constructive form of memory.

Green (2002, pp. 9-21) shows how this bidirectional action of time, appeared from the beginning and throughout Freud's writings but that this manifests in different renderings of temporality which seem to co-exist, whereby he concludes that time for Freud is heterochronic or fragmented. Freud's psychosexual theories, for example in The Three Essays on the Theory of Sexuality (1905), uphold a theory of sexual development that is sequential, linear and progressive, but that elements of time in this theory are bidirectional: it involves sexual diphasism where unresolved elements of infantile sexuality are repressed and re-present in puberty and adulthood to be worked through, entailing bidirectional elements of fixation and deferred action as well as regression. The Interpretation of Dreams (1910) refers to the pure present of the unconscious psychic dream space and the manner in which primary processes work upon unconscious memory traces, re-present them, where the dream is a form of phantastic memory construction, analogous to screen memory: the bidirectional nature of psychic life is the move. In the landmark paper Remembering, Repeating and Working Through (1914) Freud introduces a focus upon repetition and enactment: what cannot be represented (or remembered in the sense of a conscious, constructive act), continues to repeat itself (re-present, in the sense of enactment as a more primitive form of action memory), and this process manifests in the psychoanalytic setting with transferential enactment. This is extended when Freud, in Beyond the Pleasure Principle (1920) develops the concept of repetition compulsion as a manifestation of the death instinct, and Green argues, of all drives or instincts. In fact, with the Id supplanting the unconscious in this latter phase of Freud's writings (not 
replacing it, for the structural and topographic models by no means intertranslate or substitute for one another), both unconscious atemporal drives, and traces of experience, somehow exist within non-psychic space through which ego function has as its role to bind and represent these aspects of the Id. Green (2002) also highlights the significance of Mourning and Melancholia, where Freud differentiates between mourning and melancholia through a more articulated theory of intrapsychic object relations, which can be the site of forms of pathological memory. This links object relations to another form of re-presentation. He also refers to socio-cultural memory, primal fantasy (the Freud of Totem and Taboo and Group Psychology and the Analysis of the Ego) having bidirectional quality.

I would add that Freud (in Beyond the Pleasure Principle) uses the term Bindung (translated as binding) to explain these ego processes and the phenomenon of repetition compulsion. Bindung also refers to a process in which psychic trauma, seen as an extensive breach of the ego's boundaries, is compulsively repeated in symbolic activity (one recalls his discussion of the Fort-Da game). And finally, there is a later notion of Binding (such as it appears in An Outline of Psychoanalysis) as one of the major characteristics of Eros and the life instincts - the move to self-preservation, ego integrity and self-unity, as opposed to the destructive, degenerative, fragmentation of the death instinct (Entbindung). I introduce these versions of Freudian Bindung because they refer to movements toward consciousness formation, ego integrity, self unity, and later the self-preserving instinct to compulsively work through trauma via unconsciously driven symbolic relational enactments to re-establish integrity and unity. These forms of Bindung are forms of re-presentation, action and integration that are temporal, in Green's sense of bidirectional time, and link to self-function or ego function. Interestingly, when using these later conceptualizations of Bindung Freud does not return to explore the question of unconscious time. For example, in Beyond the Pleasure Principle he states:

At this point I shall venture to touch for a moment upon a subject which would merit the most exhaustive treatment. As a result of certain psycho-analytic discoveries, we are to-day in a position to embark on a discussion of the Kantian theorem that time and space are 'necessary forms of thought'. We have learnt that unconscious mental processes are in themselves 'timeless'. This means in the first place that they are not ordered temporally, that time does not change them in any way and that the idea of time cannot be applied to them. These are negative characteristics which can only be clearly understood if a comparison is made with conscious mental processes (p. 28).

We see here that in this re-assertion of a timeless unconscious Freud simultaneously turns to the requirement of directing more attention toward an understanding of conscious mental processes, the integrity and functioning of the ego. Here we have something of a critical juncture in Freud's elaboration of his metapsychology which I will not develop 
too much here: there is one movement in Freud's later work which focuses on the centrality of ego function and would no doubt be later adopted by the Ego Psychology schools; the other movement focussing on the death instinct (entbindung) in its necessary relationship with the life instincts. What is paradoxical about death is that as we have seen with the early Heidegger it may represent an ultimate horizon of non-relational, nontemporal individualization but within the existential context, it is something that is projected towards, it forms a temporal horizon. With regard to this latter movement, I would comment though that we see death figuring as a temporal concept in Heidegger's notion of Dasein as being-towards-death, projecting towards death, finding its individual authenticity in this relation to death. Extending this, there is room to analyse the creative potential of the Freudian death instinct and this may fit within the problematic of the absence of temporality in the Freudian Unconscious.

In all of this, Green (2002) uses Nachträglichkeit as a bridging concept for what he sees as a heterochronous, fragmented temporality, with an analogous history in the analysand:

Freud's heritage leaves us with an uncompleted task and we know only too well that he was constantly re-working history in all its forms. For history, he believed, could not be reduced to what is left behind in the form of visible traces (accessible to consciousness) nor to that of which traumas conserve the memory. There is not one history (great or small), but several histories within the spheres of the individual, culture and the species, which are interrelated, interwoven, overlapping and sometimes opposed - each living according to its own rhythm and its own time....And rather than giving up and opting for the simplest solution - a strictly ontogenetic point of view we should have the courage to do justice to this complexity, attempting to gather in the scattered threads of this web in order to bring together the multiple figures of time (p. 27).

This analysis has been pursued to extend notions of temporality from the foundations of Heideggerian hermeneutic ontology to a point that we can begin to think about developmental and clinical time beyond the beginnings of conceptualizations of thrownness, Care, Sicht, Entwurfen and being-towards-death. Green's (2002) analysis shows us that in the complex and open system of Freud's works, memory processes, as re-presentations, are complex and heterogonous (enactment, narrative memory, screen memory, dream work, intrapsychic object relations, primal fantasy and myth) due to the heterochronicity of time. What underpins this is a complex, heterogonous, and to Freud, timeless, field of unconscious traces, drives, instincts, processes or, relatedly, $I d$. This could be considered, in Heideggerian terms, to be an ontological field never separable 
from a hermeneutic horizon. Freud goes so far as to elaborate ego and binding processes that relate to memory work and re-presentation and Green states that although experience, finally, is heterochronous and heterogonous, ego or self function pursues cohesion, binding and meaning to constitute itself. This is work in time, although there is a double forgetting of time: "The unconscious is unaware of time but consciousness does not know that the unconscious is unaware of time" (p. 37). Ironically, his thinking of time, as Green (2002) has established it from Freud's work, itself has a bidirectional nature to it: Green is retroactively establishing a meaning and cohesion in Freud's work around time, where there wasn't one.

For Heidegger, the Freudian $I d$ and unconscious would be incoherent or aporetic concepts with metaphysical underpinnings, if not thought of in terms of forgetting, a preOntological background, a limit or a horizon. It is not inconsistent with a hermeneutic ontological orientation to think of personal time (and then developmental and clinical time) in terms of traces and re-presentations, within a broader perspective of Care, projection, futurity and being-towards-death. In this way, both the past and the future collapse within bidirectionality, where Being is a process of becoming, and the past is seen in terms of elements of potentiation and Nachträglichkeit as re-presentation.

\section{Derrida, Nachträglichkeit and Différance}

Freudian Nachträglichkeit (and along with it Verspätung or delay/deferral) played a significant role in the development of Derrida's ideas, appearing in a lecture entitled 'Freud and the Scene of Writing' at a time where Derrida is introducing a key deconstructive analysis of the suppression of writing in the metaphysical tradition which favours a metaphysics of presence, immediacy and speech, such as he had taken it up in the essays published in De la Grammatologie in 1967.

Derrida is interested in the fact that with the Freudian concepts of Nachträglichkeit and Verspätung there is an apprehension of time that is characterized by belatedness and that there is consequently no pure and simple present. Derrida questions the notion of presence and self-presence and looks subsequently into the opposition between the conscious and the unconscious in Freud, showing how Freud subverts it. According to Derrida, there does not exist in Freud an Unconscious that would be situated in a precise place and would belong to a definite time, an Unconscious that would have to be retranscribed in another place and another time (the conscious). The past is contained in the present. And Derrida (1978) makes reference to this Freudian basis in Writing and Difference:

That the present in general is not primal but, rather, reconstituted, that it is not the absolute, wholly living form which constitutes experience, that there is no purity of the living present - such is the theme, formidable for metaphysics, which Freud, in a conceptual scheme unequal to the thing itself, would have us pursue (p. 266). 
All these considerations will open the way to Derrida's concept of différance, which are, Derrida writes, "the Freudian concept of trace must be radicalized and extracted from the metaphysics of presence which still retains it."

In the context of his deconstructive analysis, Derrida is interested in the fact that Freud relies upon the metaphor of a writing machine to represent the functioning of the psyche. In the 1925 text "Note on the Mystic Writing-Pad" Freud seizes upon the metaphor of a children's toy writing machine, the Wunderblock (the Mystic Writing-Pad) to describe the functioning of the psychic apparatus in terms of the production of a permanent trace in memory whilst maintaining ongoing, indefinite capacity to receive new stimulation or percepts. In practical terms, the Mystic Writing-Pad is a device constituted of a slab of wax covered with a transparent sheet made of two layers: a transparent celluloid sheet (used as a protection) and a sheet of thin translucent waxed paper. To write, one uses a pointed stylus with which one scratches the surface and which forms grooves, which with the sheet in contact, form visible traces. To wipe off or erase these traces, one lifts the transparent sheet and the contact is interrupted. The traces remain in the slab, but the paper and celluloid sheet are again clear to be re-inscribed. Freud saw this as an ideal metaphor for the limitless reception of conscious perception, and the capacity of indefinite preservation in the unconscious that can be inscribed behind perception with indelible memory traces.

In the essay "Freud and the Scene of Writing", Derrida (1972a) notes Freud's reliance upon technological writing metaphors when he attempts to describe the action of unconscious memory. Derrida (1972a) analyses Freud's use of the "mystic writing pad" as a means of explaining unconscious memory as trace/inscription. Derrida (1972a) points to Freud's failure to recognize the existence of more sophisticated archiving technologies to use metaphorically, as well as Freud's lack of awareness of and reliance upon such technological metaphors of description. Derrida (1972a) argues that this device is used metaphorically as a supplementary machine. In loose Derridean terms, a supplement is something that, allegedly secondarily, comes to serve as an aid to something 'original' or 'natural'. Supplement has a double meaning here: it is not only secondary as a stand-in, a signifier or a representative; it also adds to and modifies.

In Derrida's deconstructive terms, the originary form that is favoured (presence, speech, essence, the natural) may indeed always be dependent upon, or altered by the supplement. In the various pieces where Derrida $(1978,1987,1998)$ analyses Freud's work, a core theme is the supplementary representation of the unconscious, and unconscious memory in particular, where all manner of technological metaphors are adopted. As described earlier, a central theme in Derrida's analysis will always relate to a key Derridean concept: that of differrance. Différance is a neologism which simultaneously refers to "differing" and "deferral". It can describe the production of meaning through such metaphors: firstly (relating to deferral) there is the notion that metaphors will never fully summon forth what they mean, but can only be defined through appeal to additional signs, words or metaphors, from which they differ. Thus, meaning is forever "deferred" or postponed through an endless chain of signification.

In a lecture subsequent to "Freud and the Scene of Writing", "La différance", Derrida (1972b) makes links between Nachträglichkeit and his own concept of différance, which has two meanings; the first refers to the determining functions of Nachträglichkeit, namely, time and deferral, the second, to difference as differentiality. Now, Derrida here 
recognizes that the notion of Nachträglichkeit has enabled him to unfold a philosophy of the future and not of the past, dialectics or synthesis. He writes:

This structure of deferral (Nachträglichkeit) forbids us . . to consider temporalisation

(temporisation) as a simple dialectical complication of the living present, an original

and unceasing synthesis (constantly returned to itself, assembled on itself, assembling)

of retentional traces and protentional openings (p. 21).

Deferral is adding, supplementing meaning, constituting the present as a form of delay beyond or different to apparently immediate temporal present that is illusory. Derrida argues that this demonstrates that writing unfolds in a discontinuous time where unconscious traces remain and can have a deferred action or presence at any time, but the originary nature of those traces, and of temporal presence, is only ever understood supplementarily, in the play of différance.

\section{Conclusion}

In all of this, we have arrived at a thinking of time, via Freud's oeuvre, in which Nachträglichkeit, re-presentation, heterochronicity and, finally, différance, can be seen to relate to a hermeneutic ontological orientation, extending Heideggerian concepts of Care, Umsicht, Entwurfen and being-towards-death, to permit a fuller understanding of historicity and potentiality that will be extended in the accompanying article when we consider developmental and clinical time.

Ultimately, Heidegger has described the temporality of existence in terms of its futurity, its embeddedness in tasks, goals and projects in which there is an intuitive understanding of process and outcomes that often defies explicit definition or representation in an objective or algorithmic sense. This temporal trajectory of existence fits within the broader horizon of mortality, worldhood and sociality from which we can only, in a derivative and secondary sense, extract ourselves to theorise or conceptualise ourselves as timeless, separate, knowable individuals. In this context, Green has ably developed Freudian psychoanalytic theory to uphold the complexity of development and background, the double action of the repetition of past in the present and the present reconstruction of the past in therapeutic work. Here, the historical or temporal unconscious background is an active field of both of the psychopathology and of potentiation in the patient's therapeutic future. And Derrida has upheld the idea that the unconscious field or background is ineliminable, always to an extent beyond our understanding and always reduced or inextricably altered through our use of technical metaphors of interpretation.

With these ideas about temporality in mind, we can now proceed to a further consideration of developmental time and the temporal field of psychotherapy. In the accompanying article, I will advance a discussion on this topic, focussing, in particular, on so-called "borderline" conditions. 


\section{Biographical Note}

- $\quad$ Paul Cammell is a psychiatrist, academic and psychoanalytic psychotherapist who originally trained in philosophy, and is affiliated with Flinders Medical Centre and Flinders University, South Australia as a senior psychiatrist and senior lecturer. He has recently been a Visiting Fellow at the Personality Studies Institute, Cornell University, New York. He is currently the Chair of the psychotherapy training committee of the Royal Australian and New Zealand College of Psychiatry. 


\section{References}

Bass, A. (2000). Difference and disavowal: The trauma of eros. Palo Alto, CA: Stanford University Press.

Bass, A. (2006). Interpretation and difference: The strangeness of care. Palo Alto, CA: Stanford University Press.

Binswanger, L. (1963). Being-in-the-world. Selected papers of Ludwig Binswanger. London, UK: Souvenir Press.

Boss, M. (1979). Existential foundations of medicine and psychology. Northvale, NJ: Jason Aronson.

Boss, M. (1963). Psychoanalysis and Daseinsanalysis. New York, NY: Basic Books.

Dallamyr, F. (1988-1989). Heidegger and psychotherapy. Review of Existential Psychology and Psychiatry, 21, 9-35.

Derrida, J. (1972a). Freud and the scene of writing. Yale French Studies, 48, 74-117.

Derrida, J. (1972b). La différance. Margins of philosophy (pp. 1-28). Chicago, IL: University of Chicago Press.

Derrida, J. (1978). Writing and difference. London, UK: Routledge.

Derrida, J. (1981). Positions. Chicago, IL: University of Chicago Press.

Derrida, J. (1983). Geschlecht I: Sexual difference, ontological difference. In Psyche: Inventions of the Other. Stanford, CA: Stanford University Press.

Derrida, J. (1987). The post card: From Socrates to Freud and beyond. Chicago, IL: University of Chicago Press.

Derrida, J. (1996). Résistances de la psychanalyse. Stanford, CA: Stanford University Press.

Eickhoff, F. (2006). On Nachträglichkeit: The modernity of an old concept. International Journal of Psycho-Analysis, 87, 1453-1469.

Freud, S. (2001). The interpretation of dreams, S. E. 5. London, UK: Hogarth Press. (Original work published 1900-1901).

Freud, S. (2001). A case of hysteria, three essays on sexuality and other works, S. E. 7. London, UK: Hogarth Press. (Original work published 1901-1905).

Freud, S. (2001). On the history of the psycho-analytic movement, papers on metapsychology and other works, S. E. 14. London, UK: Hogarth Press. (Original work published 1914-1916).

Freud, S. (2001). Beyond the pleasure principle, group psychology and other works, S. E. 18. London, UK: Hogarth Press. (Original work published 1920-1922).

Freud, S. (2001). The ego and the id and other works, S. E. 19. London, UK: Hogarth Press. (Original work published 1923-1925).

Gadamer, H. (1960). Truth and method. New York, NY: Crossroad.

Gadamer, H. (1976). Philosophical hermeneutics. Los Angeles, CA: University of California Press.

Green, A. (1978). Potential space in psychoanalysis: The object in the aetting. In S. Grolnick, \& L. Basrkin (Eds), Between reality and fantasy: Transitional objects and phenomena (pp. 167-190). New York, NY: Jason Aronson.

Green, A. (1986). On private madness. London, UK: Hogarth Press.

Green, A. (2002). Time and psychoanalysis. London, UK: Free Association Books.

Green, A. (2008). Freud's concept of temporality: Differences with current ideas. International Journal of Psychoanalysis, 89, 1029-1039.

Green, A. (2000). Science and science fiction in infant research. In J. Sandler, A.-M. Sandler, \& R. Davies (Eds.), Clinical and observational psychoanalytic research (pp. 41-73). London, UK: Karnac Books.

Heidegger, M. (1928). Sein und Zeit. Oxford, UK: Basil Blackwell.

Language and Psychoanalysis, 2014, 3 (2), 4-21

http://dx.doi.org/10.7565/landp.2014.006 
Heidegger, M. (1929). Kant and the problem of metaphysics. Bloomington, IN: Indiana University Press.

Heidegger, M. (1959-1969). Zollikon seminars: Protocols, conversations, letters. New York, NY: Northwestern University Press.

Heidegger, M. (1977). The question concerning technology. In D. Ferrell Krell (Ed.), Martin Heidegger: Basic writings (pp.3-35). New York, NY: Harper Collins

Publisher. (Original work published 1954)

Lang, H. (1997). Language and the unconscious. Leiden, The Netherlands: Brill Academic Publishers.

Loewald, H. (1978). Psychoanalysis and the history of the individual. New Haven, CT: Yale University Press.

Loewald, H. (1980). Papers on psychoanalysis. New Haven, CT: Yale University Press.

Loewald, H. (1988). Sublimation. New Haven, CT: Yale University Press.

Orange, D., Atwood, G., \& Stolorow, R. (1997). Working intersubjectively: Contextualism in psychoanalytic practice. Hillsdale, NJ: Analytic Press.

Richardson, W. J. (1963). Heidegger: Through phenomenology to thought. The Hague, Netherlands: Martinus Nijhoff.

Sass, L. (1992). Heidegger, schizophrenia and ontological difference. Philosophical Psychology, 5, 109-132.

Stolorow, R., Atwood, G., \& Orange, D. (2002). Worlds of experience: Interweaving philosophical and clinical dimensions in psychoanalysis. New York, NY: Basic Books.

Stolorow, R. (2002). From drive to affectivity: Contextualizing psychological life. Psychoanalytic Inquiry, 22, 678-685.

Stolorow, R. (2007). Trauma and human existence: Autobiographical, psychoanalytic, and philosophical reflections. New York, NY: Routledge.

Stolorow, R. (2011). World, affectivity, trauma: Heidegger and post-Cartesian psychoanalysis. New York: Routledge.

Stolorow, R., Orange, D., Atwood, G. (2001). World horizons: A post-Cartesian alternative to the Freudian unconscious. Contemporary Psychoanalysis, 37, 43-61. 